\title{
Unusual myeloid leukaemia in patient with Hodgkin's disease
}

\author{
M A HORTON, M J BARNETT, L GOFF, B CZEPULKOWSKI, J A L AMESS, \\ A G STANSFELD, T A LISTER
}

From the Departments of Haematology and Medical Oncology, St Bartholomew's Hospital, London

SUMMARY An unusual case of leukaemia in a patient with Hodgkin's disease is described. The leukaemic blast cell population was typified by the presence of a substantial proportion of binucleate and multinucleate cells, many of which had the morphological features of SternbergReed cells. The circulating and bone marrow blast cells were shown by immunophenotyping to be of myeloid origin.

The cellular origin of the neoplastic elements in the different histopathological forms of Hodgkin's disease, and of the pathognomonic Sternberg-Reed cell in particular, are unknown ${ }^{12}$ and have been a subject of considerable debate. At various times, and based on criteria of differing validity, the Sternberg-Reed cell has been proposed to have a T lymphoid, ${ }^{3}$ B lymphoid, ${ }^{4-7}$ or myeloid origin. ${ }^{8}$ In a large series of patients with Hodgkin's disease who were followed up about $5 \%$ developed a second malignancy, ${ }^{9}$ which represents a striking increase in incidence compared with that in the normal population. Although many malignancies were of a haemopoietic origin, there was no consistent pattern which might have suggested the origin to be Hodgkin's disease. The termination of Hodgkin's disease in a true leukaemic phase is a rare event $^{10-12}$ and clearly provides an opportunity for detailed analysis of the nature and origin of the malignant cell concerned.

We report a case of nodular sclerosing Hodgkin's disease terminating in a leukaemia, which was typified by the presence of multinucleate blast cells with many of the morphological features of Sternberg-Reed cells. Immunophenotypic analysis showed the cells to be of myeloid origin.

\section{Case report}

A 62 year old man presented in November 1981 with clinical stage IVB Hodgkin's disease of nodular sclerosing histological type. The appearances of a peripheral blood sample and bone marrow aspirate were normal. He was treated with six cycles of chemotherapy comprising mustine, vinblastine, pro-

Accepted for publication 6 January 1987 carbazine, and prednisolone, and clinical remission was achieved. In November 1983 he had an infradiaphragmatic relapse; this was confirmed by examination of a lymph node biopsy specimen, which showed lymphocyte depleted Hodgkin's disease. At this time the appearances of a peripheral blood sample, bone marrow aspirate, and trephine biopsy specimen were normal. Four cycles of etoposide, vincristine, and adriamycin were given, but, although he responded well, computed tomography scans showed persistent lymphadenopathy. He was observed without treatment until October 1984, when, because of progressive disease, four cycles of chlorambucil, vinblastine, procarbazine, and prednisolone were started. By February 1985 disease progression was evident and confirmed by a biopsy specimen which again showed lymphocyte depleted Hodgkin's disease. In March 1985 a peripheral blood sample and bone marrow aspirate showed features of an acute leukaemia. His clinical condition deteriorated rapidly, and he died in March 1985. Postmortem examination showed evidence of residual Hodgkin's disease in the inguinal lymph nodes; the remaining lymphoreticular tissue was extensively infiltrated by leukaemic blast cells with the same morphological features as blast cells from the blood and bone marrow.

\section{Material and methods}

HAEMATOLOGICAL AND HISTOPATHOLOGICAL TECHNIQUES

Histological examination of the lymph node biopsy specimens obtained for diagnosis and subsequent assessment was carried out by one of us (AGS) using routine techniques according to standard diagnostic 
criteria. ${ }^{1}$ Peripheral blood and bone marrow smears were stained for morphological examination and enzyme cytochemistry by standard haematological techniques.

\section{IMMUNOPHENOTYPE ANALYSIS}

Immunological analysis of the cell surface phenotype of circulating and bone marrow mononuclear cells was performed using an indirect immunofluorescence technique, essentially as described previously. ${ }^{13}$ The following monoclonal antibodies were used: antileucocyte common antigen 2D1; anti-HLA-Dr CA2; anti-T cell UCHT1 (T3), OKT11 (T11), OKT4 (T4), UCHT4 (T8); anti-B cell B1, B4, J5 (CALLA), $\mathrm{k}$ and $\lambda$ immunoglobulin light chains; antimyeloid $\mathrm{My} 7$, My9, OKM1, MO2, TG1; antimacrophage EMB11, RFD7; antimegakaryocyte AN51, J15; antierythroid (glycophorin A) R10; rabbit anti-Tdt; antiosteoclast $13 \mathrm{C} 2,23 \mathrm{C}^{14}$; anti-Hodgkin's cell $\mathrm{Ki}-1 .^{15}$

Frozen sections $(5 \mu \mathrm{m})$ of a lymph node obtained

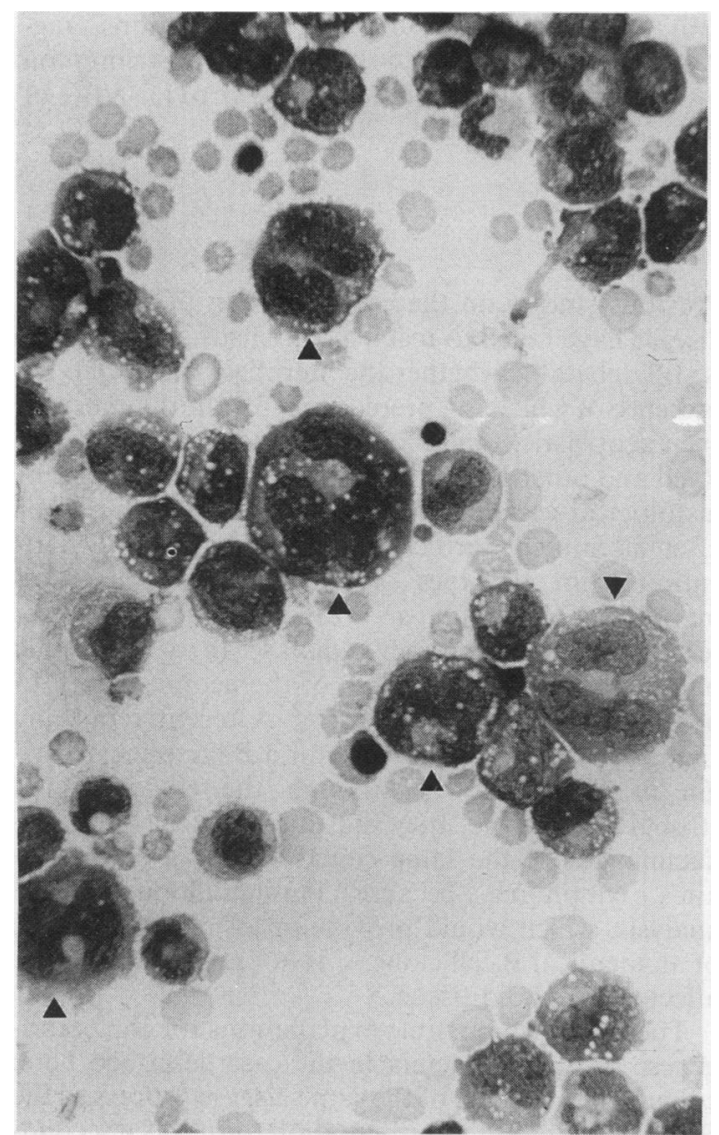

Fig 1 Morphology of May-Grünwald-Giemsa stained blast cells in bone marrow. Binucleate cells resembling Sternberg-Reed cells are arrowed. by surgical biopsy in 1985 were stained with CD 15 (TGI, a LeuMl equivalent antibody) and $\mathrm{Ki}-1$ monoclonal antibodies using an indirect immunofluoresence technique as described previously. ${ }^{13}$ These antibodies have been reported to react strongly with Sternberg-Reed cells. ${ }^{1516}$

\section{KAR YOTYPIC ANALYSIS}

Chromosomal analysis was performed using standard methods.

\section{Results}

Histological examination of the lymph node biopsy specimen obtained for diagnosis and subsequent assessment and tissue obtained at necropsy showed typical nodular sclerosing Hodgkin's disease transforming to lymphocyte depleted type. Necropsy tissue samples were not available for phenotypic examination.

Examination of peripheral blood samples and bone marrow aspirates in the leukaemic phase showed large blast cells with basophilic cytoplasm, some of which had prominent nucleoli and cytoplasmic granulation. Most blast cells were finely positive with Sudan black and non-specific esterase staining. In addition, there was a substantial population of large binucleated and multinucleated blast cells (fig 1).

The table summarises the results of phenotypic analysis of the mononuclear cells obtained from

Table Cell surface immunophenotype of blast cells

\begin{tabular}{|c|c|c|c|}
\hline \multirow[b]{2}{*}{ Specificity } & \multirow[b]{2}{*}{ Antibody } & \multicolumn{2}{|c|}{ Cells positive (\%) } \\
\hline & & Bone marrow* & Blood $\dagger$ \\
\hline $\begin{array}{l}\text { Leucocyte common } \\
\text { HLA-Dr } \\
\text { T cell }\end{array}$ & $\begin{array}{l}\text { 2D1 } \\
\text { CA2 } \\
\text { UCHT1 (T3) } \\
\text { T11 } \\
\text { OKT4 (T4) } \\
\text { UCHT4 (T8) }\end{array}$ & $\begin{array}{r}95 \\
50 \\
2 \\
0 \\
0 \\
0\end{array}$ & 95 \\
\hline B cell & $\begin{array}{l}\text { B1 } \\
\text { B4 } \\
\mathrm{J} 5 \text { (CALLA) } \\
\mathrm{k} \text { chain } \\
\lambda \text { chain }\end{array}$ & $\begin{array}{l}2 \\
1 \\
0 \\
0 \\
0\end{array}$ & \\
\hline Myeloid & $\begin{array}{l}\text { OKM1 } \\
\text { MO2 } \\
\text { TG1 } \\
\text { My7 } \\
\text { My9 }\end{array}$ & $\begin{array}{l}75 \\
30 \\
20 \\
75 \\
\text { nd }\end{array}$ & $\begin{array}{l}70 \\
90 \\
75 \\
75 \\
80\end{array}$ \\
\hline Macrophage & $\begin{array}{l}\text { EMB11 } \\
\text { RFD7 }\end{array}$ & $\begin{array}{l}0 \\
0\end{array}$ & \\
\hline $\begin{array}{l}\text { Sternberg-Reed } \\
\text { cells } \\
\text { Megakaryocytes }\end{array}$ & $\begin{array}{l}\text { Ki-1 } \\
\text { AN51 } \\
\text { J15 }\end{array}$ & $\begin{array}{l}0 \\
2 \\
2\end{array}$ & \\
\hline Osteoclasts & $\begin{array}{l}13 C 2 \\
23 C 6\end{array}$ & $\begin{array}{l}0 \\
0\end{array}$ & \\
\hline $\begin{array}{l}\text { Erythroid } \\
\text { Tdt }\end{array}$ & $\begin{array}{l}\text { R10 } \\
\text { Rabbit anti-Tdt }\end{array}$ & 2 & \\
\hline
\end{tabular}

* $50 \%$ blast cells. $\uparrow 40 \%$ blast cells. 


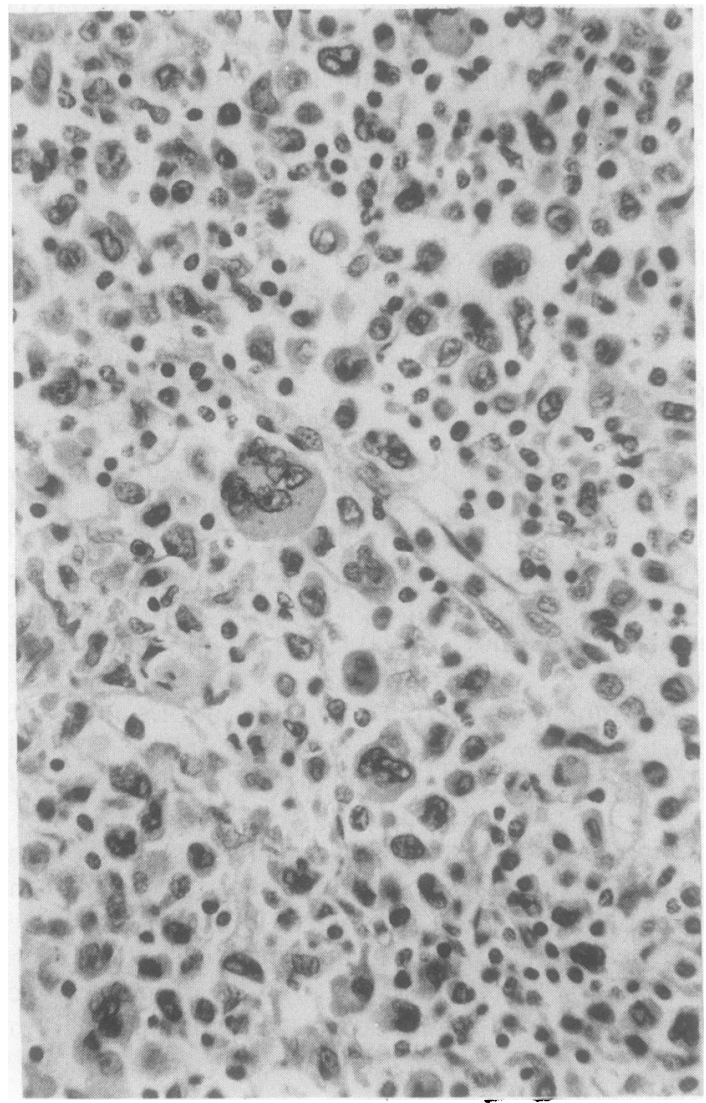

Fig 2 Morphology of cervical lymph node showing infiltration with leukaemic blast cells, many of which are multinucleate. (Haematoxylin and eosin.)

peripheral blood and bone marrow. Most of the blast cells expressed myeloid antigens (OKM1, MO2, TG1, MY7, MY9, HLA-Dr); there were some phenotypic differences between blast cells from bone marrow and those from peripheral blood, with a considerably increased expression of MO2 and TG1 by the peripheral blood blast cells. There was no evidence of expression of immature or mature $\mathrm{T}$ or $\mathrm{B}$ lymphocyte antigens or antigens characteristic of other cells lineages (table).

The most characteristic feature of the blast cells in the bone marrow, and in blast cells obtained from the spleen and lymph nodes at necropsy, was the presence of a subpopulation of cells which were large and had either multiple or lobulated nuclei (figs 1 and 2). Three types of normal haemopoietic cell types have these features: megakaryocytes, osteoclasts, and macrophage polykaryons. None of the blast cells marked with antibodies specific for osteoclasts (13C2, 23C6), ${ }^{14}$ megakaryocytes (AN51, J15), or mature tis- sue macrophages (EMB11, RFD7). They did, however, express a range of antigens typical of more immature myeloid cells, as did the mononuclear blast cells (table). It could be that the multinucleate blast cells represented an extreme form of dysmyelopoiesis. A further possibility is that they were leukaemic Hodgkin's cells. Despite the morphological similarity between the binucleate blast cells and Sternberg-Reed cells there was no expression of the $\mathrm{Ki}-1$ antigen.

The only lymph node available for frozen section immunophenotyping dated from the last biopsy. Sections were examined for the presence of cells marked by $\mathrm{Ki}-1$ and CD15 (TG1) monoclonal antibodies, which are known to idenify Sternberg-Reed cells. ${ }^{1516}$ No positive cells were found, but the material available was largerly sclerotic and hypocellular with few Hodgkin's cells.

Chromosomal analysis of the patient's blast cells showed a great diversity of karyotype with features typical of karyotype instability. The cells ranged from hypodiploid to hyperdiploid (41-96 chromosomes) with numerous, but inconsistent, translocations, fragments, and marker chromosomes. The most common rearrangements were: $\mathrm{t}(10 ; 18)(\mathrm{pll} ; \mathrm{pl} 1), 50 \%$ of cells; $\mathrm{t}(11 ; 17)(\mathrm{pl} ; \mathrm{p} 11), 20 \%$ of cells.

\section{Discussion}

Previous studies on the cellular origin of Hodgkin's disease have failed to reach a consensus. Moreover, it is still debatable whether the Sternberg-Reed cell, the presence of which is a prerequisite for the diagnosis, is even neoplastic. Immunological studies of SternbergReed and other Hodgkin's cells from the full range of histological variants of Hodgkin's disease, in situ or after attempted purification, have suggested a derivation from all types of haemopoietic cell (summarised by Dorreen et $^{7}{ }^{7}$ ). Investigation of the rare termination of Hodgkin's disease in a leukaemic phase has allowed the origin of the neoplastic cell to be studied in more detail. ${ }^{10-12} \mathrm{~A}$ recent report by Linch et al provided evidence for a B lymphocyte origin in their case. ${ }^{12}$ Although the evidence was strongly suggestive, they did not prove that the leukaemia was of the same clonal origin as the Hodgkin's lymphoma because immunoglobulin gene analysis, which would provide proof of involvement of an identical B cell clone, was not performed on the affected lymphoid tissue.

There are two possible explanations for the pathogenesis of the leukaemia in the case described here: either it formed part of the same disease process as the Hodgkin's disease at presentation, or it was a secondary leukaemia resulting from chemotherapy. We favour the former view for the following reasons. 
Firstly, the leukaemia developed at an early stage when Hodgkin's disease was evident at a number of nodal sites but was not responding to treatment. This temporal association suggests, but does not prove, that the two disease processes were related. Secondly, the morphological similarity between the binucleate leukaemic blast cells and Sternberg-Reed cells certainly supports this view, as does the neoplastic nature of the blast cells as judged by karyotype; however, as the immunological phenotype of the two cells could not be compared there can be no formal proof in this case. Thirdly, there was no prodromal phase of bone marrow hypoplasia or evidence of dyshaemopoiesis preceding the development of leukaemia. Finally, the karyotypic abnormalities were not typical of a secondary leukaemia.

The immunophenotyping of the blast cells from peripheral blood and bone marrow, both mononucleate and multinucleate, in this case provides strong evidence for a myeloid origin. There was no expression of B or T lymphoid markers, which contrasts with the clear lymphoid origin of the case reported by Linch et al. ${ }^{12}$ There is increasing evidence to support the view that Hodgkin's disease forms a complex of clinicopathological conditions, and it would therefore not be surprising that the nature of the rare cases of leukaemic transformation of Hodgkin's disease was also heterogeneous. Until the neoplastic cell(s) of Hodgkin's disease can be identified and isolated from the mixed cell population of the nodal lesions these rare leukaemias will provide the only means of analysing the origin of this intriguing disease.

We acknowledge the support of the Imperial Cancer Research Fund.

\section{References}

1 Lukes RJ, Butler JJ. The pathology and nomenclature of
Hodgkin's disease. Cancer Res 1966;26:1063-81.

2 Kaplan HS. Hodgkin's disease: biopsy, treatment, prognosis. Blood 1981;57:813-22.

3 Biniaminov M, Ramot B. Possible T lymphocyte origin of ReedSternberg cells. Lancet $1974 ;$ i:368.

4 Leech J. Immunoglobulin positive Reed-Sternberg cells in Hodgkin's disease. Lancet 1973;ii:265-6.

5 Garvin AJ, Spicer SS, Parmley RT, et al. Immunohistological demonstration of IgG in Reed-Sternberg and other cells in Hodgkin's disease. J Exp Med 1974;139:1077-83.

6 Stuart AE, Jackson E, Morris CS. The reaction of xenogeneic and monoclonal antisera with Reed-Sternberg cells. J Pathol 1982;137:129-38.

7 Dorreen MS, Habeshaw JA, Stansfeld AG, et al. Characteristics of Sternberg-Reed and related cells in Hodgkin's disease: an immunohistological study. Br J Cancer 1984;49:465-76.

8 Stein H, Uchanska-Ziegler B, Gerdes J, et al.Hodgkin and Sternberg-Reed cells contain antigens specific to late cells of granulopoiesis. Int J Cancer 1982;29:283-91.

9 Dorreen MS, Gregory WM, Wrigley PFM, et al. Second primary malignant neoplasms in patients treated for Hodgkin's disease at St Bartholomew's Hospital. Haematological Oncology 1986;4:149-61.

10 Sink LF, Clein GP. The cytogenetics and cell metabolism of Reed-Sternberg cells. Br J Haematol 1966;12:447-51.

11 Hayhoe FGJ, Burns GF, Cawley JC, et al. Cytochemical, ultrastructural and immunological studies of circulating ReedSternberg cells. Br J Haematol 1978;38:485-90.

12 Linch DC, Berliner N, O'Flynn K, et al. Hodgkin-cell leukaemia of B-cell origin. Lancet 1985; i:78-80.

13 Goff LK, Habeshaw JA, Rose ML, et al. Normal values of the different classes of venous blood mononuclear cells defined by monoclonal antibodies. $J$ Clin Pathol 1985;38:54-9.

14 Horton MA, Lewis D, McNulty K, et al. Monoclonal antibodies to osteoclastomas (giant cell bone tumors): definition of osteoclast specific antigens. Cancer Res 1985;45:5663-9.

15 Schwab U, Stein H, Gerdes J. Production of a monoclonal antibody specific for Hodgkin and Sternberg-Reed cells of Hodgkin's disease and a subset of normal lymphoid cells. Nature 1982;299:65-7.

16 Norton AJ, Isaacson PG. Granulocyte and HLA-D region specific monoclonal antibodies in the diagnosis of Hodgkin's disease. J Clin Pathol 1985;11:1241-6.

Requests for reprints to: Dr MA Horton, Department of Haematology, St Bartholomew's Hospital, London EC1A 7BE, England. 